International Journal of Education (IJE) Vol.4, No.4, December 2016

\title{
'TEACHERS' AND STUDENTS' PERCEPTION AND THE CHALLENGES OF INTRODUCING MENTORING FOR THE UNDERGRAD STUDENTS OF BANGLADESH
}

\author{
Iffat Naomee $^{1}$ and Asif Bayezid ${ }^{2}$ \\ ${ }^{1}$ Program Associate, Agami Education Foundation, Dhaka, Bangladesh \\ ${ }^{2}$ Lecturer (Adjunct), Department of Education, Prime University, Dhaka, Bangladesh
}

\begin{abstract}
Mentoring, being a widely excepted concept around the globe is a must in the field of education. However, this concept is yet not formally introduced in the education sector of Bangladesh. Mentoring service, at the moment is mostly needed for the undergrad level students of Bangladesh. Thus the purpose of this study is to explore the perception of the teachers and the students about mentoring as well as the potential barriers of formally introducing mentoring. This small scale qualitative study has been carried out in five universities of Bangladesh where the total number of respondents were fifteen including five teachers and ten students. Data was collected using semi-structured interview schedule and was analysed thematically. Findings suggest that most of the teachers and students are not quite aware of the concept of mentoring, thus proper training, infrastructural development, awareness raising programs should be conducted before formally introducing mentoring for the students.
\end{abstract}

\section{INTRODUCTION}

In some points of life, almost everyone has experienced being mentored or has been a mentor themselves, not necessarily in a formal way [1]. Mentoring means facilitating and assisting someone to attain the goal of life and not instructing someone to do specific tasks [2]. It plays an important role in impacting the classroom practice, developing potential, raising standard and achievement [3]. For the undergrad students, mentoring is particularly necessary to make the students understand the field of study [4] and to help the students in goal attainment through providing knowledge, ideas, opportunities and assistance [5].

However, in Bangladesh, the term mentoring is still unknown to many. There is no mentoring service available in the education sector of Bangladesh, neither for the teachers, nor for the students. In this competitive world it is very important yet challenging to introduce mentoring service in the education sector of Bangladesh. That is why this study on mentoring the undergrad students of Bangladesh is of particular interest to the researchers. This study focuses on the perception of the teachers and students about mentoring and the challenges of introducing mentoring in the undergrad level. Undergrad level has been chosen for the study because, from the researchers' experiences, it was found that, this stage is the most crucial one for the students where they need proper care and guidance as well as a professional mentoring to understand their area of study and future career prospects.

DOI : $10.5121 / \mathrm{ije} .2016 .4401$ 
International Journal of Education (IJE) Vol.4, No.4, December 2016

\section{DEFINITIONS}

In the National Framework for Mentoring and Coaching [6], mentoring is defined as, a structured, sustained process for supporting professional learners through significant career transitions. Coaching, on the other hand, has a narrower concern of developing specific skills and improving performance [7]. Other definitions of mentoring include, providing guidance, advice, support and feedback to a less experienced person by an experienced one [8] and, assisting and motivating someone to gain knowledge for skill development, performance management and potential maximization through which they can achieve the goal of their life [9]; whereas, coaching remains one of the aspects of mentoring focusing on development of professional practice [10].

A mentor has numerous other functions then coaching; including, communicating, demonstrating, supporting, protecting, guiding, advising, motivating, counselling, teaching, tutoring, volunteering, role modelling, proctoring, talent developing, providing psychological support and acting as a resource person [11], [12].

\section{MENTORING MODELS}

Mentoring is all about helping the learner to achieve his/her goal. There are two ways of helping a learner. One is directive which means solving the learners' problem for them, and the other one is non-directive where the mentor helps the learners to solve their own problems by themselves [13]. Studies show that the most effective mentoring relationships for the mentees' personal development are the non-directive ones [14].

Clutterbuck (2002) mentioned five styles of helping to learning along two dimensions where the two dimensions are directive versus non-directive and stretching versus nurturing, and the five styles are coaching, networking, guiding, counselling and mentoring. He also described two models of mentoring including all these styles and both the dimensions, named developmental mentoring, where mentoring is a combination of all the styles and dimensions equally, and sponsoring mentoring, where guiding and counselling is given more importance than coaching and networking [14]. Though both the models are suitable for mentoring, however the researchers' personal opinion is that there should be no prescribed model of how the mentoring should work. Depending on the needs of the mentee, his/her goals, the realities, the options and the wills, the mentor should choose the way the mentee might be mentored.

This leads to another model of mentoring which is the GROW model. Though the GROW model is basically a coaching model, but as it is a non directive model, it can be used in mentoring as well [15]. This model has some flaws as mentees now-a-day sets goals according to the realities and there might be more than one goal set for a mentee. This will make it difficult for both the mentor and the mentee to follow the GROW model and as a result this model might not be suitable to start with in a mentoring service that is thought of being introduced in Bangladesh.

Thus, for introducing mentoring in Bangladesh, the researchers would prefer the mentors and the mentees to be spontaneous in the mentoring process and just be them without thinking about any specific mentoring model to follow. It would be easier for the first timers to be natural and not follow any specific mentoring model, because, throughout the mentoring process, everything will automatically set in a format and eventually they will start following a model. 


\section{THE MENTORING RELATIONSHIP}

The mentor and the mentee share a close relationship which changes and develops over time. Different authors have defined this relationship differently. Kram (1985) divided mentoring into four stages named, initiation, cultivation, separation and redefinition [16], whereas Gray (1988) defined mentor-mentee relationship into five steps- prescriptive, persuasive, collaborative, confirmative and successful [17]. Again, Zachary (2000) described four stages of mentoring relationship named prepare, negotiate, enable and close [18]. Finally, Metros and Yang (2006) tried to break down all these models and redefined them to four stages- Identify, negotiate, facilitate and graduate [19]. All these stages defined by different authors actually refer to the changing mentor-mentee relationship over time. The mentor might not necessarily follow any particular model, rather only be aware of the gradually developing relationship.

\section{OBJECTIVES OF THE STUDY}

Knowing the importance of mentoring, it is now high time to introduce this in Bangladesh and to do so, at first it is needed to understand the perception of the students and the teachers about mentoring and the challenges they think are there in introducing this service. Thus the objectives of this study had been set as-

1. Exploring the perception of the students and the teachers of undergrad level of Bangladesh about mentoring.

2. Pointing out the challenges in introducing mentoring service at undergrad level in Bangladesh.

\section{METHODS}

Qualitative research is all about understanding how a person sees, understands and experiences things [20] and thus this small scale research was qualitative one as it tended to analyse the understanding and the experiences of the participants. For sample, 1 public and 4 private universities were selected from Dhaka city and 1 teacher and 2 students were chosen from each university using convenient sampling. This sampling strategy was applied in this research because it was accessible and most convenient [20] for the researchers. Semi-structured interview was conducted for data collection and two interview guides have been prepared for interviewing the teachers and the students. Semi-structured interview was selected as data collection tool as it is flexible and gives the participants opportunities to discuss their own issues rather than what the researcher anticipates [21]. Thematic analysis constituted of six phases, is used to analyse the data [22].

\subsection{Ethical Consideration}

BERA Ethical Guideline for Educational Research [23] has been followed throughout the study to maintain proper ethical practice. No name or means of identification has been used in the research to maintain privacy and confidentiality of the participants. The participants have been given information and consent sheet including their role and right in the study and verbal consent have been recorded from them. Others work included in the study have been referenced properly in order to avoid plagiarism. 
International Journal of Education (IJE) Vol.4, No.4, December 2016

\section{FINDINGS AND DISCUSSION}

\subsection{Present Situation}

By analysing the data, it has been found that, at present, there is no official mentoring service available in Bangladesh. The concept is new in the education sector and a good number of students do not actually have any idea of mentoring. Nevertheless, there are some services similar to mentoring, such as, advising, supervising and counselling. Students have also mentioned "The unofficial mentor" [1] who is one of the teachers helping a particular student when s/he needs help and support.

\subsection{Students' Beliefs}

All the students agreed that mentoring is necessary for them. For some, mentoring will strengthen the teacher-student rapport and for others, mentoring will help decision making. Some also explained that mentoring will help them to understand their area of study and know more about future job fields, which ultimately will lead to what Jones et. al. (2007) opined as the benefit of mentoring- career satisfaction [24].

\subsection{Teachers' Beliefs}

Unlike the students', the teachers' understand the true meaning of mentoring and its importance in the education sector of Bangladesh. They opined that mentoring is a combination of guiding, facilitating, advising and counselling and always supporting the students to choose the right career for them. Teachers also believe that, classic mentoring [25] is needed for the undergrad students to Bangladesh.

\subsection{Mentoring Experiences of the Teachers}

Some of the teachers have experienced the unofficial mentoring themselves and therefore are now being unofficial mentors of some of their students. Some teachers, who as students needed mentoring support and failed to find one, also realise the problem of the students and try to help them.

\subsection{Mentoring Experiences of the Students}

Some students explained that they were unable to find the perfect teacher and thus could not get proper support. On contrary, some of the students found an unofficial mentor who helped them throughout their academic years and are still helping them in making important decisions of life.

\subsection{Qualities of a Mentor}

According to the teachers, a good mentor should be flexible, friendly, knowledgeable, communicative, a good listener and a role model. This is similar to the findings of Roberts (1999) where the teachers felt that they need to be expressive and instrumental while being flexible and versatile [26]. Teachers, in this study, feel that s/he should have the qualities of a counsellor, a guide, an advisor, and a resource person. On the other hand, the students want a mentor who will listen to them carefully, understand their problems, and will give them genuine guidelines. 
One of the major concerns for the students in the mentoring relationship is their privacy and anonymity that means the mentor should be loyal, which is one of the qualities of the ideal mentor [27]. They also want someone, who has time for them and can relate to their situation. According to the students most of their teachers do not possess enough qualities to be a good mentor and need proper training.

\subsection{Ideal Mentoring Relationship}

An ideal mentoring relationship as the students suggested, is one where the mentor communicates well with the mentee. The best way of effective communication in the opinion of the students is listening carefully and frequently asking questions. On the other hand, the teachers believe that the best mentoring relationship occurs through sincere observation of the mentor of every activity of the mentee to understand even the hidden feelings of the mentee.

From the data it can be summed up that the ideal mentoring relationship is all about a flexible and friendly relationship with effective communication, active listening, frequent questioning, identifying mentees strengths and weaknesses, reflecting experiences and providing valuable feedback.

\subsection{Perception of Introducing Mentoring in Bangladesh}

Both teachers' and students' hold positive perception about introducing mentoring in Bangladesh. Despite some potential challenges, both the teachers and the students are hopeful about launching this new initiative for the undergrad students.

\subsection{The Challenges of Introducing Mentoring in Bangladesh}

For private universities, there are other similar services as mentoring and students can go to the teachers anytime they want; so, mentoring as a separate service is not needed. On the other hand, for public universities, the main problem is bureaucracy. Everything runs in a bureaucratic way thus takes a long time to introduce new things; that is why the university administration finds it easy not to initiate anything new. This is the greatest challenge in public universities in introducing mentoring services.

Other issues are lack of trained and motivated teachers, personal conflict between the teachers, teacher-student conflict and political involvement in education. These issues are similar to the issues identified by Schlosser and Foley (2008) which are power issues, inappropriate relationships, lack of competence of the mentors and boundary problems [28].

\section{RECOMMENDATIONS}

According to the findings of the study and the researchers' personal knowledge and experience, it can be recommended that to introduce mentoring service in undergrad level of Bangladesh, first, the teachers should be given proper training. Awareness raising programs should also be arranged in all the education institutions for both the teachers and the students. At the starting, the institutes can develop their own framework and policy for mentoring according to the needs of the students and the teachers as well as the institute. Eventually, when mentoring would be widely 
International Journal of Education (IJE) Vol.4, No.4, December 2016

acknowledged in educational institutes throughout the country, then the higher level of education administrators can develop a national mentoring policy.

\section{CONCLUSION}

Mentoring, as a method of developing others often occurs within supervisory frameworks [29]. It provides benefits to both the mentor and the mentee [30], [31]. The mentors need certain skills such as questioning, influencing and effective feedback, to make the relationship a successful one [32]. Different authors have suggested different models of mentoring, although it depends solely on the choice of the mentors to select one model or to establish a new model for their mentoring relationship. Besides, there are different stages of the mentoring relationship and in every stage the mentoring techniques might change.

In Bangladesh the concept of mentoring is new. Thus in this study, the mentoring situation of the undergrad level of Bangladesh has been examined with reference to the teachers' and the students' perception of mentoring and the potential challenges that might be faced while introducing mentoring in Bangladesh. The findings show that the participants' reaction is positive regarding introducing mentoring though there are some issues such as, organisational policy, teacher-student relationship, uneven expectations and lack of training and interest among the teachers, regarding the implementation of this new initiative. Nevertheless, some awareness raising programs like seminars and workshops on the benefits of mentoring is hoped to be helpful regarding changing the situation. In the end, it is anticipated by the participants of the research as well as the researchers that in near future, mentoring will be widely available for the undergrad students of Bangladesh.

\section{REFERENCES}

[1] Wallace, S. \& Gravells, J. (2007) Professional Development in the Lifelong Learning Sector. Mentoring. 2nd Edition. Southernhay East, Learning Matters Ltd.

[2] Connor, M and Pokora, J (2012) Coaching and Mentoring at Work: Developing Effective Practice. 2nd Edition. UK, McGraw Hill.

[3] Rhodes, C., Stakes, M. and Hampton, G. (2004) A Practical Guide to Mentoring, Coaching and PeerNetworking: Teacher Professional Development in Schools and Colleges. London, Routledge.

[4] Bush, T. and Middlewood, D. (2005) Leading and Managing People in Education. London, Sage Publications Ltd.

[5] Leung, M. L. and Bush, T. (2003) Student Mentoring in Higher Education: Hong Kong Baptist University. Mentoring and Tutoring, 11 (3), 263-272.

[6] Centre for the Use of Research and Evidence in Education (CUREE) (2005) National Framework for Mentoring and Coaching. [Online] Available from:

http://www.curee-paccts.com/files/publication/1219925968/National-framework-for-mentoring-andcoaching.pdf [Accessed 21 September, 2013].

[7] Simkins, T., Coldwell, M., Caillau, I., Finlayson, H. and Morgan, A. (2006) Coaching as an in-school leadership development strategy: experiences from Leading from the Middle, Journal of In-Service Education, 32 (3) 321-340. 
International Journal of Education (IJE) Vol.4, No.4, December 2016

[8] Haney, A. (1997) The Role of Mentorship in the Workplace. In: Taylor, M. C. (ed.) Workplace Education. Toronto, Ontario, Culture, pp. 211-228.

[9] Parsloe, E. (1992) Coaching, Mentoring and Assessing. London, Kogan Page.

[10] Hobson, A. and Sharp, C. (2005) Head to head: a systematic review of the research evidence on mentoring new head teachers, School Leadership and Management, 25 (1) 25-42.

[11] McKenna, G. (1998) Mentor Training: The key to Effective Staff Development. Principal, 77, 47-49.

[12] Philip, K. (1999) Young People and Mentoring: A literature Review for the Joseph Rowntree Foundation. Aberdeen, University of Aberdeen.

[13] Downey, M. (2003) Effective Coaching: Lessons from the Coach's Coach. 3rd Edition. Oakland, CA, Texere Publishing.

[14] Clutterbuck, D. (2002) Everyone Needs a Mentor: Fostering Talent in your Organisation. 3rd Edition. London, CIPD publishing.

[15] Whitemore, J. (2009) Coaching for Performance. 4th Edition. London, Nicholas Brealey Publishing.

[16] Kram, K. E. (1985) Phases of the Mentor Relationship. Academy of Management Journal, 26 (4), 608-624.

[17] Gray, W. A. (1988) Custom Designing Planned Mentoring Programs to Meet Contextual Needs. Vancouver, B.C., International Centre for Mentoring.

[18] Zachary, L. J. (2000) The Mentor's Guide: Facilitating Effective Learning relationships. San Francisco, Jossey Bass.

[19] Metros, S. E. and Yang, C. (2006) The Importance of Mentors. In: Golden, C. (Ed.) Cultivating Careers: Professional Development for Campus IT. Washington, DC, Educause, pp. 66-78.

[20] Braun, V. And Clarke, V. (2013) Successful Qualitative Research: A Practical Guide for Beginners. London, Sage Publications Ltd.

[21] Rubin, H. J. And Rubin, I. S. (1995) Qualitative Interviewing: The Art of Hearing Data. Thousand Oaks, CA, Sage Publications Inc.

[22] Braun, V., \& Clarke, V. (2006) Using Thematic Analysis in Psychology. Qualitative Research in Psychology, 77-101.

[23] British Educational Research Association (2011) Ethical Guidelines for Educational Research. London, BERA.

[24] Jones, K. W., Hardcastle, V. and Agnich, L. (2007) A Guide to Mentoring. Lexington, University of Kentucky.

[25] Philip, K. and Hendry, L. B. (1996) Young People and Mentoring: Towards a Typology? Journal of Adolescence, 19 (3), 189-201.

[26] Roberts, A. (1999) Androgyny and the mentoring role: An empirical study to examine for prominent mentor expectations, Mentoring \& Tutoring, 7 (2), 145-162. 
International Journal of Education (IJE) Vol.4, No.4, December 2016

[27] Melanson, M. A. (2013) Qualities of the Ideal Mentor. U.S. Army Medical Department Journal, 4751.

[28] Schlosser, L. Z. and Foley, P. F. (2008) Ethical Issues in Multicultural Student-Faculty Mentoring Relationships in Higher Education. Mentoring and Tutoring: Partnership in Learning, 16 (1), 63-75.

[29] Gassman, J. and Gleason, M. C. (2011) The Importance of Mentoring Relationships among Young Workers. New Directions for Youth Development, 2011 (S1), 55-76.

[30] Johnson, W. B. (2002) The Intentional Mentor: Strategies and Guidelines for the Practice of Mentoring. Professional Psychology: Research and Practice, 33, 88-96.

[31] Chao, G. T. (2009) Formal Mentoring: Lessons Learned from Past Practice. Professional Psychology: Research and Practice, 40, 314-320.

[32] Cranwell-Ward, J., Bossons, P. and Gover, S. (2004) Mentoring: A Henley Review of Best Practice. New York, Palgrave Macmillan. 